\title{
SYMPOSIUM ON THE IMMUNITY OF STATE OFFICIALS HORIZONTAL ENFORCEMENT AND THE ILC'S PROPOSED DRAFT ARTICLES ON THE IMMUNITY OF STATE OFFICIALS FROM FOREIGN CRIMINAL JURISDICTION
}

\author{
Chimène I. Keitner*
}

The Nuremberg principles affirmed by the U.N. General Assembly ${ }^{1}$ and formulated by the International Law Commission (ILC) provide that " $[\mathrm{t}]$ he fact that a person who committed an act which constitutes a crime under international law acted as Head of State or responsible Government official does not relieve him (sic) from responsibility under international law." 2 Few would dispute this basic principle. More contested is the question of who has authority to impose consequences on individuals for international crimes committed on behalf of states. This is because, if an individual has acted with actual or apparent state authority, imposing consequences on the individual without her state's consent runs counter to traditional notions of state sovereignty and noninterference.

Principles of sovereignty and noninterference are far from absolute. The widespread acceptance of the restrictive theory of foreign state immunity considers the commercial activities of states to be justiciable in foreign courts, not because the state is any less sovereign when it acts commercially, but because the needs of modern commercial life require placing states on a similar footing to private actors. In other words, sovereignty is not an end in itself; it is only justified to the extent that it serves other goals, such as preserving international stability or promoting human dignity. Given the centrality of sovereignty as an organizing principle of international relations, however, compromising sovereignty to promote other values requires careful consideration of the trade-offs involved.

The international community's increasing resolve to identify and punish international crimes (including war crimes, genocide, and crimes against humanity) has prompted the creation of international tribunals to try these offenses. It has also spurred the enactment of domestic legislation creating jurisdiction over certain crimes regardless of the nationality of the offender or location of the conduct. These developments have multiplied the number of jurisdictions potentially empowered to adjudicate allegations of internationally criminal conduct, including conduct performed on behalf of states. Broadly speaking, there are three non-mutually-exclusive alternatives. First, an individual's own state clearly has adjudicatory authority, although accountability must often

* Harry \& Lillian Hastings Research Chair and Professor of Law at the University of California Hastings College of the Law. She is an Adviser on the ALI's Restatement (Fourth) of Foreign Relations Law of the United States and co-author of International Law Frameworks (4th ed., forthcoming 2016).

Originally published online 14 December 2015.

${ }^{1}$ GA Res. 95 (I) (Dec. 11, 1946).

2 Text of the Nürnberg Principles Adopted by the International Law Commission, 65 UN GAOR Supp. No. 12, at 11, UN Doc. A/1316 (1950) reprinted in [1950] 2 Y.B. Int'l L. Comm'n 374, UN Doc. A/CN.4/SER.A/1963/ADD. 1 A/CN.4/L.2 at 375 (1950). 
await regime change (and even then is not guaranteed). Second, international tribunals created by the UN Security Council (acting under Chapter VII) or by an international treaty (with the ex ante consent of the official's own state) can serve this role. Third, foreign states can potentially enforce international law "horizontally."3

While the Sixth Committee of the UN General Assembly continues to debate the scope and application of the principle of universal jurisdiction, ${ }^{4}$ the ILC has been tasked with formulating principles related to immunity from foreign criminal jurisdiction. Both of these projects implicate the contours of an emerging horizontal enforcement regime. This contribution considers the parameters of horizontal enforcement, and then offers comments on the ILC's most recent work.

\section{The Role of Horizontal Enforcement}

Horizontal enforcement is nothing new, but it has generated increased attention in recent years in light of efforts to use horizontal enforcement to impose consequences on individuals who have escaped investigation or prosecution in their home states. This phenomenon is, to some extent, a corollary of the complementarity principle enshrined in the Rome Statute of the International Criminal Court, ${ }^{5}$ which relies on states (including "non-territorial" States $\left.{ }^{(}\right)$to investigate and prosecute international crimes. It also flows from the "extradite or prosecute" provisions of existing multilateral treaties that criminalize conduct (such as torture) performed under color of state law.

Ratione personae immunity from foreign criminal jurisdiction protects the ability of incumbent heads of state or government, diplomats, foreign ministers, and members of special diplomatic missions to conduct foreign relations. ${ }^{7}$ Ratione materiae immunity, which turns on the nature of the act rather than the identity of the defendant, serves different goals. As noted below, ratione materiae immunity is not the only tool for avoiding the possible excesses of horizontal enforcement, but its contours have figured prominently in debates about the international legality of prosecutions (and civil suits) against former foreign officials. (Practically speaking, the most effective tool for limiting the reach of horizontal enforcement-although one that is admittedly inconvenient from the perspective of a former official-is not to travel to foreign states where one risks prosecution or extradition.)

Some degree of horizontal enforcement is both necessary and desirable if we take the idea of personal responsibility for international crimes seriously. Yet, the specter of an international jurisdictional "free for all" should also give us pause. Rather than defaulting to blanket immunity, we should endeavor to build a robust regime for imposing consequences on individuals who have engaged in egregious conduct that avoids subjecting former officials to foreign judicial harassment for politically unpopular decisions. Relevant factors to consider might include: (1) whether an international treaty would have authorized the defendant's extradition to face charges for the alleged conduct; (2) whether there is a reasonable prospect that the defendant's conduct will be the subject of a genuine investigation in his or her home jurisdiction, and whether the victims will have access to a remedy in that jurisdiction (dismissal of charges might even be conditioned on reassurances to that effect, as they are in the context of forum non conveniens motions); and (3) whether the defendant's alleged conduct is

\footnotetext{
3 See, e.g., Chimène I. Keitner, Germany v. Italy and the Limits of Horizontal Enforcement: Some Reflections from a U.S. Perspective, $11 \mathrm{~J}$. INT’L CRIM. JUST. 167 (2013).

${ }^{4}$ General Assembly, Seventieth Session, The scope and application of the principle of universal jurisdiction (Agenda item 86).

${ }^{5}$ Rome Statute of the International Criminal Court, July 7, 1998, 2187 UNTS 90.

${ }^{6}$ ICC-OTP, Informal Expert Paper: The Role of Complementarity in Practice, para. 76 (2003).

7 See, e.g., Arrest Warrant of 11 April 2000 (Dem Rep. Congo v. Belg.), Judgment, 2002 ICJ ReP. 3, 61 (Feb. 14); Prosecutor v. Taylor, Case No. SCSL-2003-01-I, Decision on Immunity from Jurisdiction, para. 41 (May 31, 2004).
} 
sufficiently egregious to warrant a foreign state attaching consequences to that conduct on behalf of the international community as a whole (a horizontal analog of the "gravity" requirement in the Rome Statute, which serves as an additional filter to limit the permissible scope of vertical enforcement ${ }^{8}$ ). Procedures would need to be established for evaluating these factors, and one could even imagine subjecting such determinations to some sort of international oversight.

The point is that horizontal enforcement should not be, and need not be, an all-or-nothing proposition. The same is true of immunity ratione materiae, despite the tendency of commentators to frame debates about its contours in all-or-nothing terms.

\section{The Scope of Conduct-Based Immunity}

The contours of ratione materiae immunity from foreign criminal and civil jurisdiction remain contested. Given the diverse and evolving nature of views on the subject, the ILC's work will almost certainly involve an element of "progressive development" of the law. ${ }^{9}$ Otherwise, the ILC could end up entrenching rules that no longer best serve the interests of the international community.

The Special Rapporteur has acknowledged these concerns, noting in her Fourth Report that "States have repeatedly insisted that the topic of immunity of State officials from foreign criminal jurisdiction must be addressed in a way that is not detrimental to or incompatible with the ongoing efforts of the international community to combat impunity." 10 However, immunity is necessarily incompatible with combatting impunity. The question is how to balance competing values and goals. The Institut de Droit International resolved at its 2009 Naples meeting, with Lady Hazel Fox serving as Rapporteur, that "[n]o immunity from jurisdiction other than personal immunity in accordance with international law applies with regard to international crimes." 11 It remains to be seen whether the International Law Commission will adopt a similar stance.

The Special Rapporteur will formally consider the topic of ratione materiae immunity for international crimes in her Fifth Report (due out in 2016). Even so, many observations in her Fourth Report are relevant to this issue, which some ILC members reportedly "consider . . . to be the very purpose, even the only purpose" of addressing the topic of immunity at all. ${ }^{12}$ The structure of the Fourth Report risks conveying the impression that it is possible to distill an omnivalent or omnipurpose definition of acts taken in an "official capacity" —an endeavor that the ILC's mandate might appear to invite, but that is highly problematic given the variety of contexts in which this concept has been invoked. ${ }^{13}$ As the Report notes, "[c]ontemporary international law does not provide a definition of this type of act," 14 and "it cannot be concluded from the [national] judicial decisions analyzed that a consistent pattern has been uniformly followed."15 (The lack of a consistent pattern might

${ }^{8}$ Rome Statute of the International Criminal Court, art 17 (1)(d)July 7, 1998, 2187 UNTS 90; see also Margaret M. deGuzman, $\underline{W h a t}$ Is the Gravity Threshold for an ICC Investigation? Lessons from the Pre-Trial Chamber Decision in the Comoros Situation, 19 ASIL INSIGHTS no. 19 (Aug. 11, 2015).

${ }^{9}$ International Law Commission, About the Commission, Organization, programme and methods of work, Object of the Commis$\underline{\text { sion. }}$

${ }^{10}$ Int'l Law Comm'n, Fourth report on the immunity of State officials from foreign criminal jurisdiction, para. 135, U.N. Doc. A/CN.4/686 (2015) [hereinafter "Fourth report"].

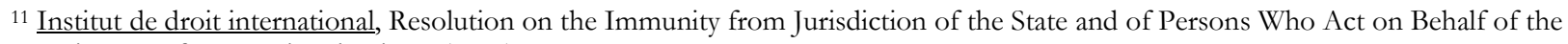
State in case of International Crimes (2009).

${ }^{12}$ Fourth report, supra note 10 , at para. 135.

13 See, e.g., $\underline{i d}$. at paras. 111,121 .

${ }^{14} \underline{I d}$. at para. 32.

$15 \underline{I d}$. at para. 51 . 
suggest that an attempt at codification is premature; at the very least, such an attempt should not stifle future legal development.)

Although some consider the "attributability" of an act to the state as the sole and decisive criterion for whether or not such an act is covered by ratione materiae immunity from foreign civil or criminal proceedings, such an approach is deeply misguided. As the Fourth Report observes, the ILC's Draft Articles on the Responsibility of States ${ }^{16}$ deliberately (and, it might be added, controversially) adopted very broad criteria for the attribution of individuals' conduct to a state. ${ }^{17}$ Mere attributability of conduct does not make such conduct "official" for any purpose other than imputing responsibility to the State-a point further highlighted by the Fourth Report's discussion of the retroactive attributability to the state of the conduct of insurrectional movements, which does not benefit from ratione materiae immunity. ${ }^{18}$ Attributability might be a necessary condition for invoking ratione materiae immunity, but it is certainly—and demonstrably—not sufficient.

The focus on attribution arises from—and is often traced to-Lady Hazel Fox's observation that

[t] he doctrine of the imputability of the acts of the individual to the State ... in classical law ... imputes the act solely to the state, who alone is responsible for its consequence. In consequence any act performed by the individual as an act of the State enjoys the immunity which the State enjoys. ${ }^{19}$

Yet we are no longer in this "classical" period, if it ever existed. That is because international law now recognizes that certain acts are attributable both to the individual and to the state. If attribution does not discharge the individual from responsibility, it is not clear why it should nonetheless "cloak" the individual with immunity.

The Fourth Report does a commendable job of integrating the important concept of dual attribution into its approach to ratione materiae immunity - a concept that will no doubt also figure prominently in the Fifth Report. The Fourth Report notes that:

(1) The ILC "accepts the existence of two distinct types of responsibility that may derive from the same act: State responsibility and individual responsibility," 20 as evidenced by article 58 of the Draft Articles on State Responsibility.

(2) " $[T]$ he principle that any act committed by an official is automatically an act of the State and engages only the responsibility of the State cannot be applied presumptively when the act is of a criminal nature."'21

(3) "[T]he immunity of State officials from foreign criminal jurisdiction ratione materiae is individual in nature and distinct from the immunity of the State stricto sensu." 22 (This is not to say that individual and state immunity are completely unconnected; as has often been observed, functional immunity is for the benefit of the state, not the individual. However, the state's immunity and the various

\footnotetext{
${ }^{16}$ Draft Articles on the Responsibility of States for Internationally Wrongful Acts, art. 7, Report of the International Law Commission on the work of its fifty-third session, 19 UN GAOR Suppl. No. 10, at 43, UN Doc. A/56/10 (2001), reprinted in [2001]2 Y.B. Int'l L. Comm'n reprinted in 2001 Y.B. Int'l L. Comm'n 26, UN Doc. A/CN.4/SER.A/2001/Add. 1 [hereinafter "Draft Articles on State Responsibility"].

${ }^{17}$ Fourth report, supra note 10, at para. 82.

18 See $\underline{i d}$. at para. 116.

${ }^{19}$ Hazel Fox, The Law of State Immunity 455 (2d ed. 2008).

${ }^{20}$ Fourth report, supra note 10, at para. 85; see also $\underline{i d}$. at para. 99.

${ }^{21} \underline{I d}$. at para. 101.

$22 \underline{I d}$. at para. 105; see also $\underline{i d}$. at para. 107.
} 
immunities accorded state officials are increasingly recognized as conceptually and doctrinally distinct, even if they are related.)

The Fourth Report emphasizes that "any criminal act covered by immunity ratione materiae is not, strictly speaking, an act of the State itself, but an act of the individual by whom it was committed." 23 Unlike some other acts (such as signing a treaty, or receiving a request issued to a State to produce official documents), most international crimes committed by state officials give rise to both state and individual responsibility. The "dual attribution" model (or what the Fourth Report calls "single act, dual responsibility"24) captures this phenomenon.

\section{The ILC's Provisional Draft Articles}

Following the submission of the Special Rapporteur's Fourth Report, the ILC's Drafting Committee provisionally adopted several Draft Articles. Since the ILC has been tasked with studying immunity from criminal (rather than civil) jurisdiction, the articles provisionally adopted by the Drafting Committee relate only to immunity from criminal jurisdiction. They include:

(1) Draft article 2(f) of the "Definitions" section, which provides that, for the purposes of the proposed Draft Articles on the Immunity of State Officials from Foreign Criminal Jurisdiction, "An 'act performed in an official capacity' means any act performed by a State official in the exercise of State authority." 25

(2) Draft article 6(1) on the scope of immunity ratione materiae, which provides that "State officials enjoy immunity ratione materiae only with respect to acts performed in an official capacity."26

The Drafting Committee previously adopted draft article 5 on persons enjoying immunity ratione materiae, which provides that "State officials acting as such enjoy immunity ratione materiae from the exercise of foreign criminal jurisdiction." 27 Taken together, these articles address the "who" and the "what" of foreign official immunity.

The Drafting Committee reportedly decided to use the term "authority" rather than "function" in draft article 2(f) "to avoid a debate on whether the commission of a crime could be considered as a State function." 28 However, it seems that the ILC will not be able to avoid this debate in its Fifth Report. Anticipating this issue, the Fourth Report considers the argument that "an international crime can [never] be regarded as an act performed in an official capacity." 29 I agree with the Special Rapporteur's opinion that this claim, stated in

23 Id. at para. 97.

${ }^{24} \underline{I d}$. at para. 99.

${ }^{25}$ Int'l Law Comm'n, Immunity of State officials from foreign criminal jurisdiction, Text of the draft articles provisionally adopted by the Drafting Committee at the sixty-seventh session, UN Doc. A/CN.4/L.865 (2015).

${ }^{26} \underline{I d}$.

${ }^{27}$ Int'l Law Comm'n, Immunity of State officials from foreign criminal jurisdiction, Text of draft articles 2 (e) and 5 provisionally adopted by the Drafting Committee on 15 July 2014, UN Doc. A/CN.4/L.850 (2014). The Chair of the Drafting Committee noted that draft article 5 might need to be revisited in light of draft article 6(1), which does not use the expression "acting as such." Int'l Law Commission, Immunity of State officials from foreign criminal jurisdiction, Statement of the Chairman of the Drafting Committee, Mr. Mathias Forteau (2015) at 6.

${ }^{28}$ Int'l Law Commission, Immunity of State officials from foreign criminal jurisdiction, Statement of the Chairman of the Drafting Committee, Mr. Mathias Forteau (2015) at 4.

${ }^{29}$ Fourth report, supra note 10, at para. 124. 
categorical terms, is "at odds with the facts,"30 but this is because the term "official capacity" is too encompassing to be useful in this context.

Reducing ratione materiae immunity to an inquiry into whether or not an act was performed in an "official capacity" in a generic sense ends up being just as reductionist—and just as potentially misleading—as asking solely whether the act in question is "attributable" to a state. Concretely, this means that although state officials "enjoy immunity ratione materiae only with respect to acts performed in an official capacity," they do not necessarily enjoy immunity ratione materiae with respect to all such acts. As with the criterion of attributability, acting in an "official capacity" is necessary but not sufficient in order for a claim of ratione materiae immunity to block the horizontal imposition of consequences on an individual alleged to have committed an international crime.

As the European Court of Human Rights recognized in Jones v. United Kingdom, state practice regarding the ratione materiae of state officials is "in a state of flux." 31 Some commentators have taken this as reason to deny the existence of a "human rights exception" to ratione materiae immunity, based on the equation "attributability $=$ official capacity $=$ ratione materiae immunity." 32 Others have adopted the opposite view, arguing that conduct such as torture can never amount to an "official act" for immunity purposes. ${ }^{33}$ A third view, advanced here, resists a one-size-fits-all approach to immunity ratione materiae, and instead advocates calibrating such immunity as part of an integrated approach to delineating the parameters of horizontal enforcement. Whether such an approach is realistic given the wide range of stakeholders and the intensity of divergent interests remains to be seen.

${ }^{30} \underline{I d}$.

${ }^{31}$ Jones v. United Kingdom, 2014-II Eur. Ct. H. R. 32, 214.

32 See, e.g., Ingrid Wuerth, Pinochet's Legacy Reassessed, 106 AJIL 731, 744 (2012).

33 See, e.g., William S. Dodge, Is Torture an "Official" Act-Reflections on Jones v. United Kingdom (Jan. 15, 2014, 1:46 AM). 